\title{
Global Burden and Challenges of Melioidosis
}

\author{
David AB Dance 1,2,3,* (D) and Direk Limmathurotsakul 2,4,5,* (iD) \\ 1 Lao-Oxford-Mahosot Hospital-Wellcome Trust Research Unit (LOMWRU), Vientiane, Laos \\ Centre for Tropical Medicine \& Global Health, University of Oxford, Oxford OX3 7FZ, UK \\ 3 Faculty of Tropical Medicine and Infectious Diseases, London School of Hygiene and Tropical Medicine, \\ London WC1E 7HT, UK \\ 4 Mahidol-Oxford Research Unit (MORU), Bangkok 10400, Thailand \\ 5 Faculty of Tropical Medicine, Mahidol University, Bangkok 10400, Thailand \\ * Correspondence: David.d@tropmedres.ac (D.A.B.D.); direk@tropmedres.ac (D.L.)
}

Received: 23 January 2018; Accepted: 24 January 2018; Published: 29 January 2018

Melioidosis, an infectious disease caused by the environmental bacterium Burkholderia pseudomallei, has remained in the shadows for far too long. Described over 100 years ago by Alfred Whitmore in Rangoon [1], the disease is so neglected that it is not even on any of the lists of neglected tropical diseases, despite the fact that it probably kills more people each year than diseases that are much better known, such as leptospirosis and dengue [2]. We aim to set the record straight.

In the first few years after its discovery, melioidosis was considered a relatively rare infection confined to areas where colonial medical services had been established, for example by the British in Burma (now Myanmar) [1], Ceylon (now Sri Lanka) [3] and the Federated Malay States (now Malaysia) [4], the French in Indochina (now Cambodia, Laos and Vietnam) [5-7], and the Dutch in the Dutch East Indies (now Indonesia) [8-10]. It was the French in Indochina who proved that the organism was a saprophyte rather than a zoonosis as had originally been suspected [11,12]. It was discovered for the first time in northern Australia in 1949 [13], although it appears that this is really where it actually originated [14]. B. pseudomallei appears to have spread from there to southeast Asia, and thence to Africa and the Americas $[15,16]$. The disease gained brief notoriety as a cause of infection amongst French and American troops serving in Southeast Asia [17-19]. Its unusual ability to remain latent after acquisition and cause a fatal disease many years later has given rise to the nickname 'Vietnam Time Bomb' [20]. B. pseudomallei has more recently been categorised as a 'Tier 1 Select Agent' because of its biothreat potential (https:/ / www.ecfr.gov/cgi-bin/retrieveECFR?gp= $\& S I D=8 a 4 b e 60456973 b 5 e c 6 b e f 5 d f e a f f d 49 a \& r=P A R T \& n=42 y 1.0 .1 .6 .61)$.

Undoubtedly, it was the work of the Infectious Disease Association of Thailand that led to the recognition that melioidosis was actually a greatly-underestimated public health problem in some parts of the world. In 1985, they organised a meeting devoted to melioidosis that highlighted 686 cases of the disease occurring in Thailand over a relatively short time period [21]. This heralded a new wave of interest in the disease that has culminated in this current special issue of Tropical Medicine and Infectious Diseases. Writing in 1991, after spending 4 years observing what an important disease melioidosis was in northeast Thailand [22], one of us reviewed existing evidence and suggested that the disease was probably far more common worldwide than was currently appreciated [23]. This was not a new idea, as Fournier had made similar suggestions some 3 decades earlier [24,25]. The reasons for its under-recognition are a lack of diagnostic microbiology laboratories serving the rural poor in the tropics, who are most likely to acquire melioidosis, and a lack of familiarity and awareness amongst medical and laboratory staff, where such laboratories are available. More recently, the prediction has been vindicated by growing numbers of reports of the disease in new places, and increasing recognition within known endemic areas [26,27]. In 2016, the first attempt was made to estimate the global burden of human melioidosis in terms of cases and deaths, the resulting prediction being 165,000 and 89,000 per year, respectively, a mortality burden similar to that of measles [2]. 
Now, two years on from this modelling study [2], the time is right to take stock of what we have learned since then. In this issue, we have combined articles from countries and regions around the world that summarise the current status, including what is known locally about the burden of melioidosis, and the key challenges facing local clinicians, laboratory staff and public health and policy makers, in relation to this elusive but common and fatal disease. We hope that this will become a key source of information for those who share our concern and are taking actions against this disease.

Conflicts of Interest: The authors declare no conflict of interest.

\section{References}

1. Whitmore, A. On the bacteriology of an infective disease occurring in Rangoon. Br. Med. J. 1912, 2, $1306-1308$.

2. Limmathurotsakul, D.; Golding, N.; Dance, D.A.B.; Messina, J.P.; Pigott, D.M.; Moyes, C.L.; Rolim, D.B.; Bertherat, E.; Day, N.P.J.; Peacock, S.J.; et al. Predicted global distribution of Burkholderia pseudomallei and burden of melioidosis. Nat. Microbiol. 2016, 1, 15008. [CrossRef] [PubMed]

3. Denny, C.R.; Nicholls, L. Melioidosis in a European. Ceylon J. Sci. 1927, 2, 37-40.

4. Stanton, A.T.; Fletcher, W. Melioidosis: Studies from the Institute for Medical Research, Federated Malay States; No. 21; John Bale, Sons \& Danielson Ltd.: London, UK, 1932.

5. Vielle, A.; Morin, H.G.S.; Massias, C. Un nouveau cas de mélioïdose en Cochinchine. Bull. Soc. Med. Chir. Indoch. 1926, 4, 459-465.

6. Pons, R.; Advier, M. Melioidosis in Cochin China. J. Hyg. 1927, 26, 28-30. [CrossRef] [PubMed]

7. Mesnard, J.; Joyeux, B.G. Un cas de mélioïdose au Tonkin. Bull. Soc. Med. Chir. Indoch. 1929, 7, 32-39.

8. De Moor, C.E.; Soekarnen; van de Walle, N. Melioidosis op Java. Mededeeling uit het Geneeskundig Laboratorium te Weltevreden 1932, 72, 1618-1635.

9. Hulshoff, A.A. Een geval van meliö̈dosis. Geneeskd Tijdschr Ned Indie 1933, 73, 1218-1222.

10. Pet, M.A.; Fossen, A. Melioidosis der inwendige organen (melioidosis of internal organs). Geneeskd Tijdschr Ned Indie 1934, 74, 976-981.

11. Vaucel, M. Présence probable du bacille de Whitmore dans l'eau de mare au Tonkin. Bull. Soc. Pathol. Exot. 1937, 30, 10-15.

12. Chambon, L. Isolement du bacille de Whitmore à partir du milieu extérieur. Ann. Inst. Pasteur 1955, 89, $229-235$.

13. Cottew, G.S. Melioidosis in sheep in Queensland; a description of the causal organism. Aust. J. Exp. Biol. Med. Sci. 1950, 28, 677-683. [CrossRef] [PubMed]

14. Pearson, T.; Giffard, P.; Beckstrom-Sternberg, S.; Auerbach, R.; Hornstra, H.; Tuanyok, A.; Price, E.P.; Glass, M.B.; Leadem, B.; Beckstrom-Sternberg, J.S.; et al. Phylogeographic reconstruction of a bacterial species with high levels of lateral gene transfer. BMC Biol. 2009, 7, 78. [CrossRef] [PubMed]

15. Sarovich, D.S.; Garin, B.; De Smet, B.; Kaestli, M.; Mayo, M.; Vandamme, P.; Jacobs, J.; Lompo, P.; Tahita, M.C.; Tinto, H.; et al. Phylogenomic analysis reveals an Asian origin for African Burkholderia pseudomallei and further supports melioidosis endemicity in Africa. mSphere 2016, 1. [CrossRef] [PubMed]

16. Chewapreecha, C.; Holden, M.T.; Vehkala, M.; Valimaki, N.; Yang, Z.; Harris, S.R.; Mather, A.E.; Tuanyok, A.; De Smet, B.; Le Hello, S.; et al. Global and regional dissemination and evolution of Burkholderia pseudomallei. Nat. Microbiol. 2017, 2, 16263. [CrossRef] [PubMed]

17. Patterson, M.C.; Darling, C.L.; Blumenthal, J.B. Acute melioidosis in a soldier home from South Vietnam. J. Am. Med. Assoc. 1967, 200, 447-451. [CrossRef]

18. Brundage, W.G.; Thuss, C.J.J.; Walden, D.C. Four fatal cases of melioidosis in US soldiers in Vietnam. Am. J. Trop. Med. Hyg. 1968, 17, 183-191. [CrossRef] [PubMed]

19. Weber, D.R.; Douglass, L.E.; Brundage, W.G.; Stallkamp, T.C. Acute varieties of melioidosis occurring in US soldiers in Vietnam. Am. J. Med. 1969, 46, 234-244. [CrossRef]

20. Anonymous. Viet Nam's “time bomb”. Time 1967, 89, 6.

21. Punyagupta, S. Review of 686 cases and presentation of a new clinical classification. In Melioidosis; Punyagupta, S., Sirisanthana, T., Stapatayavong, B., Eds.; Bangkok Medical Publisher: Bangkok, Thailand, 1989; pp. 217-229. 
22. Chaowagul, W.; White, N.J.; Dance, D.A.; Wattanagoon, Y.; Naigowit, P.; Davis, T.M.; Looareesuwan, S.; Pitakwatchara, N. Melioidosis: A major cause of community-acquired septicemia in northeastern Thailand. J. Infect. Dis. 1989, 159, 890-899. [CrossRef] [PubMed]

23. Dance, D.A.B. Melioidosis: The tip of the iceberg? Clin. Microbiol. Rev. 1991, 4, 52-60. [CrossRef] [PubMed]

24. Fournier, J. A zoonosis gaining ground: Melioidosis. Med. d'Egypte 1960, 9, 23-54.

25. Fournier, J. La mélioïdose et le b. de Whitmore. Controverses épidémiologiques et taxonomiques. Bull. Soc. Pathol. Exot. Filiales 1965, 58, 753-765. [PubMed]

26. Currie, B.J.; Dance, D.A.B.; Cheng, A.C. The global distribution of Burkholderia pseudomallei and melioidosis: An update. Trans. R. Soc. Trop. Med. Hyg. 2008, 102 (Suppl. S1), S1-S4. [CrossRef]

27. Limmathurotsakul, D.; Wongratanacheewin, S.; Teerawattanasook, N.; Wongsuvan, G.; Chaisuksant, S.; Chetchotisakd, P.; Chaowagul, W.; Day, N.P.; Peacock, S.J. Increasing incidence of human melioidosis in northeast Thailand. Am. J. Trop. Med. Hyg. 2010, 82, 1113-1117. [CrossRef] [PubMed]

(C) 2018 by the authors. Licensee MDPI, Basel, Switzerland. This article is an open access article distributed under the terms and conditions of the Creative Commons Attribution (CC BY) license (http://creativecommons.org/licenses/by/4.0/). 